\title{
Social protection in contemporary capitalism: counter-reforms and regression of social rights
}

Capitalism can change, maintaining its predatory essence. Historical processes add characteristics to this system that may mark eras. We are living the era of capital financialization, with the leadership of transnational mega-corporations that operate with relative unity in the global strategy of accumulation and domination.

Over the last forty years, this configuration of capitalism has expanded in the context of the structural crisis of the capital since the beginning of the 1970s and has deepened since 2008, when a new recessionary cycle spread throughout the world, driven by the housing crisis in the United States. In the course of the crisis, financial capital placed itself at the center of economic and social relations and, together with transnational industrial groups, took over them all.

This financial power is multi-determined, but it has gained support in the public debt. It pressured the state in favor of liberalizing markets and policies to attract lending, such as high-interest rates, overvalued stock markets, and forced privatizations, thereby fueling the financial market.

The symbiosis between economic institutions and the state is part of the strategy of the economic elites to regain power in the face of the exhaustion of the strategies of accumulation adopted post World War II until the mid-1970s. From then on, a broad strategic project has been coordinated by the economic and political elites of world powers, based on neoliberal perspective, transformed into the central guideline of the economic thought and administration. Neoliberalism as a theory of political-economic practices, states that human well-being is enhanced by liberating individual entrepreneurial freedom and capacities in contexts of solid rights to private property and the free market. From this point of view, it is up to the state to create and preserve institutional structures appropriate for these practices. This explains the state's participation in shaping contemporary capitalism, in which the constitutive institutions of financial capital are central - banks and institutional investors, such as pension funds, collective investment funds, insurance corporations, and mutual funds.

Thus, the intervention of the imperial and multinational bourgeoisie subordinates the state to achieve its goals of political domination and accumulation. It leaves its predatory marks on all continents such as the deepening of social inequalities, the high levels of poverty at the same time that we observe an increasing concentration of wealth, the widespread unemployment and the expansion of precarious working conditions. Also, it is possible to see a regression of social rights and the appropriation of the public fund by parts of the capital, the criminalization of social movements resisting to oppression and exploitation of the working class, the loss of democratic spaces, the expansion of neoconservatism and ultra-right, and the environmental devastation.

In Latin America and the Caribbean, a region of a dependent economy, high levels of poverty and income concentration intensify social inequality, and there are few social policies able to reduce this problem. In these countries, social security (especially the pension scheme, which stands out in the region's history of social protection) suffers continuous restrictions. Labor rights, healthcare, and public education, public investments in culture, leisure, housing, sports, public transport, and public policies for food and job creation are subject to restrictions and setbacks. In several countries in Latin America and the Caribbean, state-owned companies operating in areas of basic infrastructure and communication (such as electricity, potable water, sewage, and telephone) were privatized.

(C) The Author(s). 2019 Open Access This article is distributed under the terms of the Creative Commons Attribution-NonCommercial 4.0 International License (http://creativecommons.org/licenses/by-nc/4.0/), which permits use, distribution, and reproduction in any medium, since it's for non-commercial purposes, and provided you give appropriate credit to the original author(s) and the source, provide a link to the Creative Commons license, and indicate if changes were made. 
The historical processes of the countries have given them different degrees of regression of social rights. However, the neoliberal perspective is still guiding the policies, despite the workers' resistance.

Against this backdrop, this thematic issue of the Revista Katálysis entitled Social protection in contemporary capitalism: counter-reforms and regression of social rights presents various perspectives and aspects of the critical theories, which allow a broad understanding of the theme. The articles emphasize the reality in Brazil and Argentina, countries that are under the effect of a sharp political turn to the right, with a frightening advance of the neoliberal project.

Opening this issue, the article "Capital accumulation, crisis, and labor market in modern Brazil," by Gustavo Mello, Maurício de Souza Sabadini, and Henrique Braga, connects the changes in the Brazilian labor market with the dynamics of the world's capitalist economy of the last decades in the context of deepening of the capital crisis. Then, Alexandre Aranha Arbia presents "Analysis of labor policies in Brazil: How can Marx contribute?". Innovatively, based on Marx's thinking about nineteenth-century English factory legislation, the author investigates labor legislation in Brazil, from the President Vargas government to that of President Temer, to show its links to capital accumulation. In "Brazilian social protection system as an instrument to fight poverty," Lauro Francisco Mattei discusses the importance of social protection systems to fight poverty, based on the systems of the countries of central capitalism and the criticism of the Brazilian system.

As for the reflections about Argentina, the work "Labor, social rights and social protection in Argentina based on the neoliberal reconstruction," by Malena Victoria Hopp and Eliana Lijterman, analyzes the reorganization of the social protection system in Argentina, started at the end of 2015, following the neoliberal guidelines. The authors support their work on the so-called inclusion to labor strategic policies that stimulate labor cooperatives and the commercialization of social rights.

The article "Expropriation of the public servant: managerialism as a project" by Tiago Siqueira dos Reis problematizes what the author calls social expropriation of the Brazilian state apparatus, based on the idea of managerial administration in public institutions defended by President Cardoso's government between 1995 and 2002.

The judicialization of rights is the perspective used by Michaele Lemos Peixoto and Hayeska Costa Barroso to discuss social rights in the article "Judicialization and social security: Restriction or enforcement of social rights". The authors problematize the phenomenon of judicialization as a mechanism for access to rights in the face of restrictions of regulations and the limits of judicial processes.

In the article "The Brazilian capitalist state: Analysis of social rights in times of neoliberal orthodoxy" by Patrícia Soraya Mustafa, the author analyzes the document Uma Ponte para o Futuro [A bridge to the future], which guided President Temer's government, as well as the measures actually carried out by President Temer's administration. The discussed measures include the labor counter-reform, the Constitutional Amendments 93 and 95, and the proposal of counter-reform of social security. The study points out the consequences of these measures to the working class. The work "Minimum income and social protection: historical, theoretical and contextual aspects" by Robson Roberto da Silva studies the history of minimum income programs and their relationship with social protection standards in the countries of central capitalism and Latin America.

The article "Capitalist interests and challenges for the enforcement of social rights: challenges and regressions," by Laís do Nascimento Vidal Lage, shows the capitalist offensive to civilizational achievements in Brazil, with emphasis on recent years.

After that, back to the contributions regarding Argentina, Judit Evelyn Frank, Rosana Pieruzzini and Maricel Salera present the article "Social intervention and the turns in politics". The authors discuss issues raised during a research project on social intervention and its relationship with the processes of territoriality and deterritoriality in the city of Paraná (province of Entre Ríos, Argentina). The article offers an operational design of the key concepts, applied to the empirical data collected in the case study. In the study "Social responsibility as social protection strategy in modern capitalism," the authors Mariangel Sánchez and Tânia Maria Santana dos Santos build on the counter-reform of the state in the 1980s in Latin America, where the privatization strategy took place under the so-called Social Responsibility, to show that this approach potentializes the bourgeois hegemony.

Closing the thematic section of the journal, the article "The social and the common: neoliberalism, bio-politics, and universal basic income," by Murilo Duarte Costa Corrêa and Cainã Domit Vieira, advocates the universal basic income as a bio-political tool capable of catalyzing what the authors call institution of the common, which, in their opinion, contain the alternative to the mystifying dualism between neoliberalism and welfarism.

Bruna Carolina Bonalume and Adriana Giaqueto Jacinto present the opening article of the non-thematic section, "Juvenile incarceration: The historical legacy of selectivity and criminalization of poverty". The study addresses juvenile imprisonment, and the way violence is part of this population's daily life, including the selectivity of justice in societies characterized by inequality of gender, class and race/ethnicity. 
The article "The unity of capital financialization and self-reproduction: Marxian assumptions and modern elements," by Rodrigo Fernandes Ribeiro, analyzes the unity between the process of expanded capital selfreproduction and the modern phenomenon of financialization, based on Marx's foundations.

In "The Program Puntos de Cultura and its beneficiaries: A case study in the region of Buenos Aires," the author Diana Bento de Mello deals with the implementation of the Puntos de Cultura [Places of culture] program, based on the perspective of the program's beneficiaries. The study emphasized the period from 2016 when there were changes in the initiative's management. The article "Political emancipation and the struggle for the right to the city," by Ada Kallyne Sousa Lopes, presents theoretical reflections on the historical ground in which the struggle for the right to the city in Brazil takes place and the limits arising from the historicalstructural determinations to the political emancipation of the city. The debate continues with "Quilombola territoriality and labor: A non-dichotomic relationship between culture and nature," by Maria Sueli Rodrigues de Sousa and Joaquim José Ferreira dos Santos. The study considers the Quilombola work and territoriality as non-dichotomic processes if the category work is not mediated by owners of the means of production, in which the relationship between culture and nature occurs in a dynamic in which the human beings build themselves and the environment where they live and work.

The final article is a review of the work by Fábio Régio Bento, "Marxism and Religion: Revolution and religion in Central America," produced by Vinicius Pinheiro de Magalhães, according to whom the work allows one to glimpse counter-hegemonic possibilities in religious conservatives and reactionary spaces.

The first issue of 2019 preserves the academic commitment of Revista Katálysis to nourish the critical debate on capitalist society, offering valuable articles with consistent arguments that highlight the contemporary characteristics of capitalism and the regression of social rights. There is no doubt that these academic productions will shed light on and promote social struggles in defense of essential rights to political and human emancipation in bourgeois society, which presupposes libertarian sociability without exploitation, alienation, and oppression. Thus, in dark and daring times, this issue of our journal is a glimmer of light. The hope is that, in taking advantage of this publication, many of you will move forward, strengthening the anti-capitalist struggles.

Maria Lucia Lopes da Silva, Brasília, 5 January 2019.

\section{References}

Emenda Constitucional No. 93, de 8 de Setembro de 2016, Diário Oficial da União [D.O.U] de 9.9.2016. Retrieved from http:// www.planalto.gov.br/ccivil_03/Constituicao/Emendas/Emc/emc93.htm

Emenda Constitucional No. 95, de 15 de Dezembro de 2016, Diário Oficial da União [D.O.U] de 15.12.2016. Retrieved from http:// www.planalto.gov.br/ccivil_03/constituicao/emendas/emc/emc95.htm

Lei No. 13.467, de 13 de Julho de 2017, Diário Oficial da União [D.O.U] de 14.7.2017. Retrieved from http://www.planalto.gov.br/ ccivil_03/_Ato2015-2018/2017/Lei/L13467.htm

Fundação Ulysses Guimarães, \& Partido do Movimento Democrático Brasileiro. (2015). Uma Ponte para o Futuro. Retrieved from https://www.fundacaoulysses.org.br/wp-content/uploads/2016/11/UMA-PONTE-PARA-O-FUTURO.pdf

Proposta de Emenda à Constituição PEC 287/2016, de 5 de Dezembro de 2016. Retrieved from http://www.camara.gov.br/proposicoesWeb/ fichadetramitacao?idProposicao $=2119881$

\section{Maria Lucia Lopes da Silva}

lucialopes198@gmail.com

Doctor of Social Policy from Universidade de Brasília (UnB)

Assistant Professor at the Universidade Brasilia (UnB)

\section{UnB}

Campus Universitário Darcy Ribeiro - Asa Norte

Brasília - Distrito Federal - Brazil

CEP: 70.910-900 